\title{
5 Democracy, Aristocracy, or Monarchy? Representative Democracy
}

In the penultimate chapter of the Universal Constitution, Dobruska reflects on three different political models - democracy, aristocracy and monarchy. He wants to establish which is the best government for the future society that is born from the collapse of the Ancien Régime. It should be noted that the term "government" is understood in the eighteenth century in a manner similar to what is found, for example, in The Spirit of the Laws of Montesquieu, ${ }^{274}$ that is its the sense of "political regime", and not in its contemporary meaning of "organ of executive power".

Let's stick to the metaphor of society as a body composed of different members, and imagine what can happen if some members are privileged over others, if they are fed and cared for more than the rest:

In fact, if the blood flows faster, or heads towards the head more abundantly than usual, the eyes acquire a more vivid sparkle, the cheeks are more colorful, but it is an advantage that lasts little. Since nature has determined, for each part of the body, a portion of the juices necessary for its growth and maintenance, if you increase the supply to one part of the body to the detriment of the others, this produces the destruction of everything else. This apparent improvement [of a part of the body] is only a trap; this external brilliance hides the disease, and death watches over its victim. ${ }^{275}$

It's a clarifying metaphor. If a society adopts an aristocratic and monarchic regime, it privileges certain social groups or individuals at the expense of the great mass. In the long run, these regimes will destroy society itself.

If we move from the body to aristocratic and monarchic regimes, "the appearance is no less deceptive; the outward opulence of a small group hides from us the

274 The first thirteen books of The Spirit of the Laws of Montesquieu are devoted to the three types of government, which Raymond Aron calls a political sociology. It is "un effort pour réduire la diversité des formes de gouvernement à quelques types, chacun de ceux-ci étant défini, tout à la fois, par sa nature et son principe" (Aron, Les étapes de la pensée sociologique, 30). In the second book entitled On the laws that derive directly from the nature of the government Montesquieu begins by noting that "there are three species of governments: republican, monarchical, and despotic": See Montesquieu, The complete Works of M. de Montesquieu, 9.

275 Philosophie sociale, 233: [En effet, si le sang flue plus vite, ou se porte vers la tête en plus grande abondance que de coutume, les yeux acquièrent un éclat plus vif, les joues sont plus animées, mais cet avantage dure peu. La nature ayant déterminé pour chaque partie du corps, la portion de sucs nécessaire à sa croissance et à son entretien, l'augmentation de recette d'une partie au détriment des autres, produit la destruction de toutes; car cette apparence de mieux, n'est qu'an piège; cet extérieur brillant cache la maladie, et la mort veille sa victime].

Ә Open Access. (C) 2022 Silvana Greco, published by De Gruyter. (c) BY This work is licensed under the Creative Commons Attribution 4.0 International License.

https://doi.org/10.1515/9783110758825-005 
misery of a million individuals; and the imminent death of the whole body is the inevitable consequence of this abusive and destructive regime". ${ }^{276}$

\subsection{Representative Democracy}

According to the Philosophie sociale, the compass that allows one to orient oneself in one's choice of political regime is always the primitive sovereign in the state of nature. ${ }^{277}$ Representative democracy is the only healthy political regime for society, precisely because it is the one followed by the primitive sovereign in the state of nature.

In fact, only democracy can give each member, or individual, whatever his or her strength and ability, a portion of food commensurate with his or her needs. ${ }^{278}$ In other words, in a representative democratic regime there is a balance or, if you like, a strictly fair balance of interests, which ensures the strength and health of the State. From this balance comes the general benefit and well-being which is given by the sum of the assets of each member:

In the primitive state of pure nature, all members contribute to the needs and contentment of the whole body; none [of the members] is dispensed from this task on the basis of a privilege; no member is preferred and no one can dwell in a state of guilty neutrality when it comes to the common interest in relation to the purpose, the principle.

The stomach asks for food; the eye discovers it; the feet take it to the refreshing source, the nourishing root, which the hands promise to take immediately. If the hand finds a resistance, a dispute follows immediately. It overcomes the obstacle or rejects the opponent who has less strength; and if it has more strength, the animal escapes and its paws save it from danger. In this situation, there is no struggle for functions, between the eye and the hand, the foot and the ear. Each of these members involuntarily and with all their means, shall co-operate in the defense and mutual assistance of the other. Each member uses all his knowledge in favor of the supreme one (the body). ${ }^{279}$

276 Ibidem, 234: [Ici l'apparence n'est pas moins trompeuse; l'opulence extérieure d'un petit nombre, nous cache la misère d'un million d'individus: et la mort prochaine du corps entier, est la suite inévitable de ce régime abusif et destructeur].

277 Ibidem, 233.

278 Ibidem, 234.

279 Ibidem, 156: [Dans l'état primitif de pure nature, tous les membres concourent aux besoins et au contentement de tout le corps; aucun ne s'en dispense par privilège; aucun ne s'y porte par préférence, et nul ne peut demeurer dans une coupable neutralité, quand il s'agit de leur égal intérêt relativement au but, le principe. L'estomac demande des alimens, l'œil les découvre; les pieds portent à la source rafraîchissante, à la racine nutritive, que la main prend aussitôt le soin d'arracher. Si elle trouve une résistance, s'il survient une dispute, elle 
Here, society is conceived as a "social body" similar to what happens in the natural state, and democracy is the only system that satisfies the principle of harmonic distribution of resources, so as to maintain the vital balance of society.

The democracy to which the Philosophie sociale refers is the representative one, which differs from the direct one. If in direct democracy decisions for the community are taken by the holders of political rights, in representative democracy they are not taken by all citizens with the right to vote, but by the representatives that the citizens elect.

\subsection{The Three Powers: Legislative, Executive, and Judicial}

The Philosophie sociale questions the principles that allow the functioning of representative democracy. Dobruska substantially takes up the political theory of the division and separation of the three powers - the legislative, executive and judicial - elaborated almost half a century earlier by Montesquieu in The Spirit of the Laws (1748), an immense and fundamental work, which Montesquieu himself considered as "the fruit of the reflections of a lifetime". ${ }^{280}$

In the sixth chapter of the eleventh book, On the laws that form political liberty, with regard to the constitution, Montesquieu affirms the need for a division of powers within the State:

In every government there are three sorts of power: the legislative; the executive in respect to things dependent on the law of nations; and the executive in regards to matters that depend on the civil law.

By virtue of the first, the prince or magistrate enacts temporary or perpetual laws, and amends or abrogates those that have been already enacted. By the second, he makes peace or war, sends or receives embassies, establishes the public security, and provides against invasions. By the third, he punishes criminals, or determines the disputes that

surmonte l'obstacle ou repousse l'adversaire inférieur en forces; et s'il est supérieur, l'animal fuit, et ses jambes le sauvent du danger. Dans cette situation, point de lutte dans les fonctions, entre l'œil et la main, le pied et l'oreille, mais chacun de ces membres concourt involontairement et de tous ses moyens, à la défense et assistance réciproque de l'autre conclusion, chaque membre déploie tout son avoir en faveur du tout principal (le corps)].

280 Charles-Louis de Montesquieu, Pensées - Le Spicilège, edition established by Louis Desgraves, Paris: Laffont, 1991, nr. 1868: [Cet ouvrage est le fruit des réflexions de toute ma vie, et, peut-être, que, d'un travail immense, d'un travail fait avec les meilleures intentions, d'un travail fait pour l'utilité publique, je ne retirerai que des chagrins, et que je serai payé par les mains de l'ignorance et de l'envie]. 
arise between individuals. The latter we shall call the judiciary power, and the other, simply, the executive power of the state. ${ }^{281}$

As is well known, Montesquieu's theory, which has become the fulcrum of modern democracies, provides not only for the division of powers, but also for their separation.

Only with this separation is it possible to avoid tyranny and guarantee what is most desirable in a State, the freedom of individuals and the possibility for them to have control over their own lives:

When the legislative and executive powers are united in the same person, or in the same body of magistrates, there can be no liberty; because apprehensions may arise, left the same monarch or senate should enact tyrannical laws, to execute them a tyrannical manner.

Again, there is no liberty if the judiciary power be not separated from the legislative, the life and liberty of the subject would be then the legislator. Were it joined to executive power, the judge might behave with violence and oppression.

There would be an end of every thing, were the same man, or the same body, whether of the nobles or of the people, to exercise those three powers, that of enacting laws, to exercise those three powers, that of enacting laws, that of executing the public resolutions, and of trying the causes of individuals. ${ }^{282}$

281 Montesquieu, L'esprit des lois, I. 11. 6 (Idem. Tutte le opere, 1219: [Il y a, dans chaque État, trois sortes de pouvoirs; la puissance législative, la puissance exécutrice des choses qui dépendent du droit des gens, et la puissance exécutrice de celles qui dépendent du droit civil. Par la première, le prince ou le magistrat fait des lois pour un temps ou pour toujours, et corrige ou abroge celles qui sont faites. Par la seconde, il fait la paix ou la guerre, envoie ou reçoit des ambassades, établit, la sûreté, prévient les invasions. Par la troisième, il punit les crimes, ou juge les différends des particuliers. On appellera cette dernière la puissance de juger; et l'autre, simplement la puissance exécutrice de l'État]. See Idem, The complete Works of M. de Montesquieu,198.

282 Loc. cit. (Montesquieu, Tutte le opere, 1220): [Lorsque, dans la même personne ou dans le même corps de magistrature, la puissance législative est réunie à la puissance exécutrice, il n’y a point de liberté; parce qu'on peut craindre que le même monarque ou le même sénat ne fasse des lois tyranniques, pour les exécuter tyranniquement. Il n'y a point encore de liberté, si la puissance de juger n'est pas séparée de la puissance législative, et de l'exécutrice. Si elle était jointe à la puissance législative, le pouvoir sur la vie et la liberté des citoyens serait arbitraire; car le juge serait législateur. Si elle était jointe à la puissance exécutrice, le juge pourrait avoir la force d'un oppresseur. Tout serait perdu, si le même homme, ou le même corps des principaux, ou des nobles, ou du peuple, exerçaient ces trois pouvoirs; celui de faire des lois, celui d'exécuter les résolutions publiques, et celui de juger les crimes ou les différends des particuliers]. See Idem, The complete Works of M. de Montesquieu, 199. 


\subsection{Legislative Power and the Enactment of Laws}

It is on the basis of the premises laid down by Montesquieu that Dobruska, in the seventh chapter of his Universal Constitution, questions legislative power.

The task of legislating is entrusted to the legislative body (le corps législatif). According to the Philosophie sociale, this body is made up not of all the people, but of one part only of them. The holders of political rights elect their representatives, to whom they entrust the task of representing moral faculties, sentiment and reason, to seek and express determination through the principle and for the principle $^{.283}$

This means that the legal bases of the law must be based on the moral faculties of individual citizens, in view of the general interest (the principle), which is the preservation of the social self.

For Dobruska, the law is "the expression of the determination of moral faculties, directed from the principle and for the principle". ${ }^{284}$ In other words, the law expresses the moral faculties of a part of the members of the people - the elected representatives in the assembly. It must be based on the principles of the Universal Constitution.

What are such moral faculties, whether they be held by the legislative body or by elected citizens? According to our author, "man essentially possesses two moral faculties: reason and feeling". ${ }^{285}$ However, these two faculties are not always in agreement with each other; on the contrary, they often disagree. Sometimes reason wants something that repels feeling, and vice versa. It is conscience that will determine whether man should listen to his own feeling or reason.

The law is the result of a process, in which the various members of the legislative body propose certain rules of conduct. These are the rules of conduct of the moral faculties, of reason and of the sentiment of the legislators.

When discussing the definition of a new law, the members of the legislative body should reflect on the needs of the social self, starting with the individual man:

See, feel and reason about the needs of the great social self, according to the individual man, according to your judgment and your insights. Work, in such a way that your legislation reflects what happens in yourself, where the voices of reason and feeling alternately

283 Dobruska, Philosophie sociale, 20: [Le corps législatif est le délégué du peuple, pour représenter les facultés morales, le sentiment er la raison pour chercher et pour exprimer la détermination par le principe et pour le principe].

284 Ibidem, 119: [La loi est l'expression de la détermination des facultés morales, dirigées par le principe, et pour le principe].

285 Ibidem, 115. 
become higher and more powerful; in a word, that each of you, according to his conscience, alternately relies on that of the two faculties which results to him as the most useful and the most applicable for the principle. ${ }^{286}$

The mediating authority will end the discussion and debate during the lawmaking process and determine the final law.

From what we have just said it is clear that, for Dobruska, the "legislative body is delegated by the people, to represent moral faculties, feeling and reason, so as to ensure the self-preservation of individual citizens and society". ${ }^{287}$

It should be pointed out that, if the legislative body ceases to represent the moral faculties of the people, its mission is null and void, because it has not achieved its aim.

In the Philosophie sociale, the justification and foundation of the legislator deviate from those of the political philosophy of Jean-Jacques Rousseau. If, for the latter, the foundation of the legislator resides in the general will (and not in the will of all), which has as its object the common good of the deliberative body, ${ }^{288}$ for Dobruska it must instead be based on law.

Not only "the laws must be based on law but, in turn, law can only be based on the principle by which it is determined".

\subsection{Executive Power}

After analyzing the legislative power, the Philosophie sociale briefly mentions the executive power, which is interconnected with the legislative one. Once the legislature has defined its laws and behaviors, it is necessary for the executive to implement what has been decided.

It is clear that, for Dobruska, there is a direct link between the legislative and executive powers. And, in fact, he states that there is only one power, "both legislative and executive". 289

286 Ibidem, 118: [Voyez, sentez et raisonnez sur les besoins du grand moi social d'après l'homme individuel, d'après votre jugement et vos lumières. Travaillez, de manière qu'il en soit dans votre législation ainsi que chacun de vous voit arriver en lui-même, ou la voix de la raison et du sentiment devient alternativement plus haute et plus puissante; en un mot, que chacun de vous fasse suivant sa conscience, dominer alternativement celle des deux faculté qui lui résultera comme la plus utile et la plus applicable pour le principe].

287 Ibidem, 120.

288 Alessandro Ferrara, “Autenticità, normatività dell'identità e ruolo del legislatore in Rousseau”, in La filosofia politica di Rousseau, eds., Giulio Maria Chiodi and Roberto Gatti (Milano: Franco Angeli, 2012), 29.

289 Ibidem, 119. 


\subsection{The Judicial Power: Of Penalties and Crimes}

Once the legislature has enacted the laws and the executive has put them into practice, a function and specific bodies must also be provided for in order to determine whether the laws have been correctly applied or whether an infringement has been committed. In the latter case, if citizens fail to comply, they must be punished with penalties.

Although Dobruska does not dwell on the judiciary and its main organs, such as the judiciary or the public prosecutor's office, he devotes a brief chapter the fourteenth of his Philosophie sociale - to "punishments and crimes". ${ }^{290}$

The title naturally evokes the masterpiece of the Milanese Illuminist Cesare Beccaria, Dei delitti e delle pene, published in 1764 in Livorno ${ }^{291}$ and translated a year later into French. ${ }^{292}$

Given the wide diffusion and recognition that Beccaria's work had among the philosophes throughout Europe, including French intellectuals - Diderot, Helvétius, Buffon, d'Holbach, d'Alembert and up to Voltaire, who dedicated an important Commentary to it in $1766^{293}$ - it is very likely that Dobruska also knew the book.

Dobruska asks himself: "What criteria should be used to punish a person who commits a crime?". His answer is clear: the penalties for those who commit a crime must be based on the nature and proportionality of the crime committed. In other words, if the violation of the law concerns the civil sphere, a penalty enshrined in the civil code will follow. If the infringement concerns criminal matters, then criminal law will have jurisdiction. For a very slight transgression, there will also be a slight sanction; for a serious transgression there will be a severe penalty. ${ }^{294}$

In the case of a very serious crime, is it permissible to sentence the offender to the death penalty? According to the Universal Constitution, the death penalty

290 Ibidem, 218-119.

291 Cf. Cesare Beccaria, Dei delitti e delle pene (Livorno: Coltellini, 1764). The essay by the jurist and philosopher Cesare Beccaria proposed an important reform of criminal law. It was meant to introduce a "reduction in repressive intervention (today we would say "minimum penalty law"), [. . . ] refusal of torture and request for a general reduction in penalties". See Alberto Burgio, "Tra diritto e politica. Note sul rapporto Beccaria-Montesquieu," Rivista di Storia della Filosofia 51 (1996): 661.

292 Cesare Beccaria, Traité des Délits et des Peines, traduit de l'italien d'après la troisième édition, revue et corrigée et augmentée par l'auteur, avec des additions de l'auteur qui n'ont pas encore paru en italien (Lausanne [but Paris] 1766. The translator was André Morellet (1727-1819).

293 Burgio, "Tra diritto e politica," 659.

294 Dobruska, Philosophie sociale, 219. 
can only be imposed on those who have jeopardized the security and existence of the entire social body.

The proximity to Beccaria's thought is obvious. The Milanese jurist, in fact, theorized a drastic reduction of the death penalty to two cases: "when the 'power' and 'relationships' of a citizen represent threats to the 'security of the nation' and when 'his death is the only real brake to divert others from committing crimes", 295

According to Dobruska, the argument for this principle (the death penalty for those who endanger the safety of society as a whole) derives from the observation of what is happening in nature. In fact, the man who puts his own security at risk, risks dying, that is, "to be punished with death". ${ }^{296}$

\subsection{Election of Civil Servants}

Having defined the political regime and the three types of power, the second set of principles concerns the election of civil servants.

The first principle of this set concerns public officials, who are true representatives of the people, and whose election takes place in two different ways: (i) directly, by the people themselves, or (ii) through an electoral body, elected with general consent, and endowed with powers for the election of officials. ${ }^{297}$

The second principle concerns government representatives:

The election of each member of the legislative body, of all officials, however modest their task may be, shall be made by roll call aloud. No official will be able to obtain any post without this formal procedure. ${ }^{298}$

The third principle is to determine who should represent the people:

[. . .] the most capable and most suitable members must be employed as representatives by unanimous choice of all the other members in defense of and at the service of society as a whole since the government must assimilate its functions according to the regime of nature, which is the only just and precise form of government. ${ }^{299}$

295 Burgio, "Tra diritto e politica," 662.

296 Dobruska, Philosophie sociale, 218-219.

297 Ibidem, 160.

298 Ibidem, 169: [L'élection de chaque membre du corps législatif inclusivement, tous les fonctionnaires, si petit que soit leur emploi, se doit faire par appel nominal à haute voix, et aucun fonctionnaire ne pourra parvenir à aucune place sans cette formalité].

299 Ibidem, 158: [C'est ainsi que doit se conduire le gouvernement du nouveau corps (la société) dans chaque circonstance, les membres les plus capables, et les plus propres doivent être employés représentativement par le choix unanime de tous les autres, à la défense et au service du grand tout car le gouvernement doit assimiler ses fonctions au régime de la nature, qui 
For Dobruska, the members who deserve to be elected as representatives of the government (political regime) are those who have developed and perfected their intellectual faculties. ${ }^{300}$

Moses Dobruska finally reflects, in the fourth group of principles, about the duration of the mandate of the government representatives. Mandates should last for as little time as possible, to avoid one of the social pathologies of the Ancien Régime, that is, the abuse of power by those who govern. Moreover, it is not acceptable for representatives of the people to be confirmed for life, that is, for an unlimited period of time. ${ }^{301}$

In order to prevent abuse of power by public officials, even during their term of office, it is the duty of the people to monitor their activities. In fact, "the people are always at the same time monarch and subject”. 302

\subsection{The Defense of the State and the Just War}

In the seventh chapter of the Universal Constitution, Dobruska asks whether war is just or unjust, and whether the use of armed force by a state is permissible and ethically acceptable.

It is right that a State should use armed force when it wants to defend a society that fights for freedom and equality of rights for each citizen, and that seeks to satisfy the appetite, developed at the highest levels. The use of war, on the other hand, is ethically unjust when it is not motivated by the general interest, which we have outlined here. It would then be a tyrannical war, contrary to the general interest and to to the founding principle of the Universal Constitution. ${ }^{303}$

\subsection{Social Education}

Dobruska has presented us with his Universal Constitutions. In each chapter, a specific theme has been examined in depth, and at the end of the chapter the

est l'unique forme du gouvernement juste et exacte, ou chaque fonctionnaire est un véritable représentant du corps entier, et ou l'élection de chaque membre se fait par le consentement du corps entier].

300 Ibidem, 159.

301 Ibidem, 169.

302 Ibidem, 170: [C'est ainsi que le peuple reste toujours en même-terms le monarque et le sujet].

303 Ibidem, 129. 
principles, or rather the regulatory rules necessary to build a representative democratic society, have been set out. The set of all the principles forms the framework (tableau), which is to be exhibited in the assemblies of the popular sections and the legislative body. Every people, taking into account its geographical and climatic situation, will find in the tableau freedom and happiness, indispensable to realize the second part of the Constitution. Since, as we know, the first part of the Constitution is the guarantee on which the second part rests, the people will no longer have to fear oppression or abuse.

We have already briefly discussed the educational value of the Universal Constitution. It is a concept, one of pedagogy at the service of law and democracy, which already finds full expression in Montesquieu. In the fifth chapter of the fourth book of The Spirit of the Laws, which bears the significant title of $E d$ ucation in the Republican Government, we read the following:

It is in a republican government that the whole power of education is required. [. . .]

This love is peculiar to democracies. In these alone the government is intrusted to private citizens. Now, the government is like every thing else: to preserve it, we must love it. [. . .]

Every thing, therefore, depends on establishing this love in a republic; and to inspire it ought to be the principal business of education: but the surest way of instilling it into children is for parents to set them an example. ${ }^{304}$

The difference between Montesquieu's approach and what is found in the Philosophie sociale, in terms of democratic education, lies rather in the motivations that are called upon to implement the educational process. Montesquieu appeals to the concept of virtue:

Virtue in a republic is a most simple thing; it is a love of the republic; it is a sensation, and not a consequence of acquired knowledge; a sensation that may be felt by the meanest as well as by the highest person in the state. When the common people adopt good maxims, they adhere to them steadier than those we call gentlemen. It is very rare that corruption commences with the former: nay, they frequently derive from their imperfect light a stronger attachment to the established laws and customs.

304 Montesquieu, L'esprit des lois, IV. 5: [C'est dans le gouvernement républicain que l'on a besoin de toute la puissance de l'éducation [. . . ] Cet amour est singulièrement affecté aux démocraties. Dans elles seules, le gouvernement est confié à chaque citoyen. Or, le gouvernement est comme toutes les choses du monde; pour le conserver, il faut l'aimer [. . .] Tout dépend donc d'établir, dans la république, cet amour; et c'est à l'inspirer, que l'éducation doit être attentive, mais, pour que les enfans puissant l'avoir, il y a un moyen sûr; c'est que les pères l'aient eux-mêmes] (Idem, Tutte le opere, 976-978). See Idem, The complete Works of M. de Montesquieu, 43-44. 
The love of our country is conducive to a purity of morals, and the latter is again conducive to the former. The less we are able to satisfy our private passions, the more we abandon ourselves to those of a general nature. How comes it that monks are so fond of their order? It is owing to the very cause that renders the order insupportable. Their rule debars them all those things by which the ordinary passions are fed; there remains, therefore, only this passion for the very rule that torments them; the more austere it is, the more it curbs their inclinations, the more force it gives to the only passion left them. ${ }^{305}$

The strategy proposed by Dobruska is partly different, in focusing on "interest" as a concrete benefit of democracy, rather than on an idealistic call for democratic pietas:

In a word: the form of democratic government must have real charm and advantages: either yes or no. If it did not have them, it would be worth nothing, it would have to be rejected and it would not deserve for us to deal with it; but if it has them, as is true, we only have to say: the form of republican democratic government has advantages, real and sublime beauties, which are freedom, equal rights. ${ }^{306}$

For the liberalist Dobruska, citizens must have a clear understanding of the benefits of democratic freedom. The benefits of freedom - such as the enjoyment of private property, freedom of the press, freedom of religion - must be understood through a cognitive process that also involves emotions. Think of the joy of owning a house, the happiness of being able to express one's ideas, the feeling of peace and trust of those who do not suffer discrimination because of their religious faith:

305 Ibidem, V. 2: [La vertu dans une république est une chose très simple: c'est l'amour de la république; c'est un sentiment, et non une suite de connoissances: le dernier homme de l'Etat peut avoir ce sentiment, comme le premier. Quand le peuple a une fois de bonnes maximes, il s'y tient plus long-tems, que ce qu'on appelle les honnêtes-gens. Il est rare que la corruption commence par lui. Souvent il a tiré, de la médiocrité de ses lumières, un attachement plus fort pour ce qui est établi. L'amour de la patrie conduit à la bonté des mœurs, et la bonté des mœurs mène à l'amour de la patrie. Moins nous pouvons satisfaire nos passions particulières, plus nous nous livrons aux générales. Pourquoi les moines aiment-ils tant leur ordre? C'est justement par l'endroit qui fait qu'il leur est insupportable. Leur règle les prive de toutes les choses sur lesquelles les passions ordinaires s'appuient: reste donc cette passion pour la règle même qui les affligent. Plus elle est austère, c'est-à-dire, plus elle retranche de leurs penchans, plus elle donne de force à ceux qu'elle leur laisse” (Idem, Tutte le opere, 994-996). See Idem, The complete Works of M. de Montesquieu, 52.

306 Dobruska, Philosophie sociale, 211: [En un mot: il faut que la forme du gouvernement démocratique ait oui ou non, des charmes et des avantages réels. Si elle n'en n'avoit pas, elle ne vaudroit rien, il fauchoit la rejeter, et elle ne mériteroit point que l'on s'en occupât; mais si elle les a, comme il est très - véritable, nous n'avons qu'à dire: la forme du gouvernement démocratique républicain à des avantages, des beautés réelles et sublimes, qui sont la liberté, l'égalité des droits]. 
All we need is to develop these real and sublime advantages into a constitution, to bring them to the feeling and reason of youth, and thus sow the seeds of human dignity for the true democrat. By only this means, by this unique vessel of light, this only true principle of a democratic republic, will disappear the fear of seeing a large part of our fellow French citizens, drag on, so to speak, aristocratic principles, and transmit them from generation to generation, according to the great number of aristocrats who are still among us..$^{307}$

For Dobruska, therefore, education is the knowledge of the interests and advantages that democratic principles, contained in the Constitution, confer on citizens (Fig. 5). The first and main of these advantages is undoubtedly freedom, which allows the individual to develop their own desires, material and intellectual.

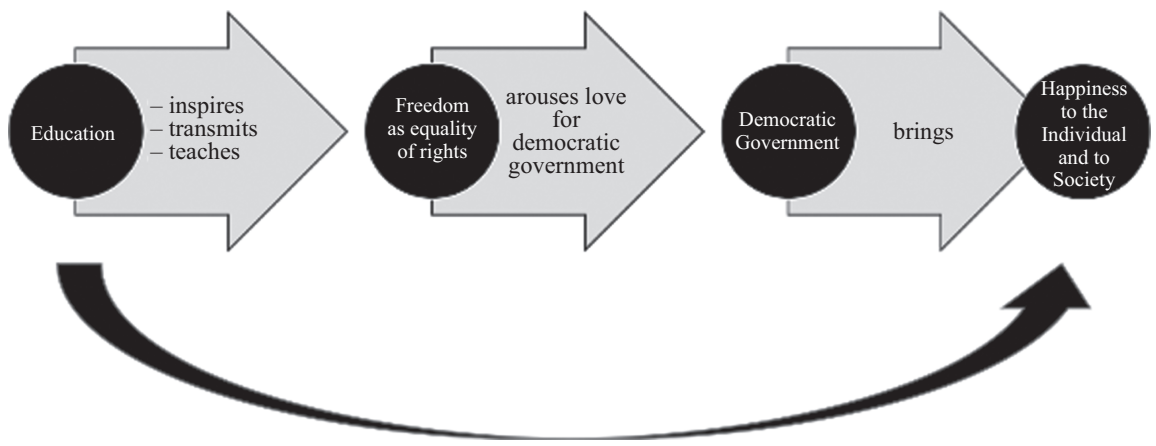

Fig. 5: The Formative Process and the Goals of Education, according to the Philosophie Sociale of Moses Dobruska.

Source: author.

In order to educate young people on democratic principles, the Universal Constitution must be an inspiring one. Like Montesquieu, Dobruska is convinced that learning is a process that also deeply involves emotionality. That is why

307 Ibidem, 217: [On n'a besoin que de développer ces avantages réels et sublimes dans une constitution, de les porter au sentiment et à la raison de la jeunesse, et de semer ainsi le germe de la dignité de l'homme, pour le vrai démocrate. Par ce seul moyen, par cette bâse unique de lumière, ce seul vrai principe d'une république démocratique, disparoîtra la crainte de voir une grande partie de nos concitoyens François, s'éterniser pour ainsi dire dans les principes aristocratiques, et les transmettre de génération en génération, d'après la grande quantité d'aristocrates qui sont encore parmi nous]. 
the principles must be "felt" and internalized emotionally. It is interesting to remark that this emotional dimension of learning, which we see emerging in the Philosophie sociale, will only be deepened in the social sciences from the 1980s onwards. ${ }^{308}$

308 Tina Hascher, "Learning and Emotions. Perspectives for Theory and Research," European Educational Research Journal 9 (2010): 13-27. On the subject of emotions in sociological research, see Helena Flam, Soziologie der Emotionen. Eine Einführung (Konstanz: UVK, 2002); Katharina Scherke, Emotionen als Forschungsgegenstand der deutschsprachigen Soziologie (Wiesbaden: Springer, 2009); Massimo Cerulo, Sociologia delle emozioni (Bologna: Il Mulino, 2018). 